\title{
STRATEGIC ENVIRONMENTAL ASSESSMENT (SEA) OF SOCIO-ECONOMIC SYSTEMS: A SYSTEMATIC REVIEW
}

\author{
Jolanta TAMOŠAITIENĖa, Oleg KAPLIŃSKI \\ ${ }^{a}$ Department of Construction Technologies and Management, Civil Engineering Faculty, \\ Vilnius Gediminas Technical University, Sauletekio al. 11, 10223 Vilnius, Lithuania \\ ${ }^{\mathrm{b}}$ Faculty of Architecture, Poznan University of Technology, 60-965 Poznan, Poland
}

Received 19 December 2012; accepted 03 November 2013

\begin{abstract}
Today, Strategic Environmental Assessment (SEA) of Socio-Economic Systems exists in micro, meso and macro environments. A complicated process is required to find a rational solution that would include a large number of problems and criteria. Therefore, existing MCDM methods must be used as well as new ones developed. Notwithstanding SEA of Analysis of Socio-Economic Processes, there is little research examining factors of use of MCDM methods; thus, a more in-depth analysis should be undertaken. This study applied a systematic search of literature. A total of 73 papers from the academic literature containing such terms as 'Strategic Environmental Assessment (SEA)', 'Socio-Economic Processes (SEP)', 'Socio-Economic Systems (SES)', 'Social Systems (SS)', 'Economical Systems (ES)', 'Decision-Making (DM)' and 'Multi Criteria Decision-Making (MCDM)' were identified and reviewed. As to the eligibility problem in Strategic Environmental Assessment (SEA), criteria included studies on both Social and Economic Systems \& Processes that examined development and trends related to SEA of Socio-Economic Processes. MCDM methods, assessment processes, data extraction and analysis were completed in all relevant studies. General activity fields in Strategic Environmental Assessment (SEA) of Socio-Economic Systems were analysed. The key issues of SEA in micro, meso and macro environment, Socio-Economic Systems and Socio-Economic Processes factors were prominent across all researched categories. As far as the analysis of Socio-Economic Systems \& Processes, decision makers should be aware of the problem in its complexity and undertake multi-stage decision-making. To honour the contribution made by Prof Valentinas Podvezko contribution in the field of Decision-Making (DM) to Strategic Environmental Assessment (SEA) of Socio-Economic Systems using MCDM methods, and to commemorate his 70th anniversary, this article also highlights his academic career and research.
\end{abstract}

Keywords: Strategic Environmental Assessment (SEA), Socio-Economic, processes, system, MCDM, Decision-Making, strategy.

Reference to this paper should be made as follows: Tamošaitienė, J.; Kapliński, O. 2013. Strategic Environmental Assessment (SEA) of Socio-Economic Systems: a systematic review, Technological and Economic Development of Economy 19(4): 661-674.

JEL Classification: C15, C80, E22.

Corresponding author Jolanta Tamošaitienè

E-mail: jolanta.tamosaitiene@vgtu.lt 


\section{Introduction}

Strategic Environmental Assessment (SEA) for identifying and assessing potential impact is used worldwide. SEA covers many areas, and one of them is the Analysis of Socio-Economic Systems and Processes. The analysis of SEA systems with principles of sustainability and complexity of outlook has become an integral part of decision-making.

The paper presents the development of Strategic Environmental Assessment (SEA) of Socio-Economic Systems in Quantitative Complex evaluation of Socio-Economic Processes during last eighty years. A systematic analysis of literature on the aspects of SEA and Decision-Making (DM) were identified and reviewed, as well as the eligibility problem in Strategic Environmental Assessment (SEA). The criteria included studies of both Social and Economic Systems \& Processes that examined development and trends related to SEA of Socio-Economic Processes. MCDM methods, assessment processes, data extraction and analysis were completed in all related studies. Development trends of Quantitative Complex evaluation of SEA of Socio-Economic Systems \& Processes are presented in this paper.

In the seventies, most efforts were focused on practical research results and their practical application. The paper shows traditions, development and application of MCDM methods for Quantitative Complex evaluation of Socio-Economic System and Processes during the period under study.

\section{The Strategic Environmental Assessment (SEA) of Socio-Economic Systems using MCDM methods}

Strategic Environmental Assessment (SEA) is evolving as a mechanism that attempts to assess systematically the environmental impacts of decisions made at, what is conventionally called, levels of strategic decisions (Partidario 1996). SEA aims to incorporate environmental and sustainability considerations into strategic decision-making processes, such as the formulation of policies, plans and programmes. In order to be effective, the assessment must take the real decision-making process as the departure point (Nilsson, Dalkmann 2001). Such diversity of approaches to SEA, while enriching debate, is critically confusing the relationship of SEA with other planning and impact assessment tools. SEA should be conceptualised as a framework, defined by core elements that are incrementally integrated into policy and planning procedures and practices, whatever decision-making system in place (Partidario 2000). Spatial and temporal scales in SEA can be used are considered. Some arguments underline that other dimensions in temporal scales, which are crucial for SEA, may need to be considered: the generational time scale (the temporal scale across generations) and the decisional time scale (the temporal scale that is relevant for making strategic decisions) (Partidario 2007).

SEA has been the focus of considerable dialogue, increasing regulatory attention and emerging evidence of application together with decision-making processes (Nitz, Brown 2001).

Strategic Environmental Assessment (SEA) is argued to provide a sound basis for informed decision-making toward sustainability (Geneletti 2013). Good management of the environment and natural resources protects health, reduces vulnerability to natural disasters, improves livelihoods and productivity, spurs economic growth based on natural resources, 
and enhances human well-being (Ahmed, Sanchez-Triana 2008). No one SEA methodology will apply to all strategic actions and in SEA contexts: we must begin to think in terms of an array of SEA tools from which the appropriate one(s) can be selected to meet the needs of the particular circumstances (Brown, Thérivel 2000; Stoeglehner et al. 2009).

In terms of environmental assessment, decision-making theory ensures appropriate practical use of Strategic Environmental Assessment (SEA) for 'real' decision-making and procedural flexibility. While it is acknowledged that a purely professional and technological paradigm to SEA is something of the past, it is proposed that leaving the design of 'flexible' SEA to the will of proponents and stakeholders might ultimately render it incapable of protecting the environment (Fischer 2003, 2007).

SEA follow-up is complex because of the complicated nature of strategic decision-making: follow-up to SEA is needed and useful to ensure the key objectives of controlling, learning and informing on strategic planning processes (Partidário, Arts 2005).

The traditional and new development of MCDM methods in the field of Quantitative Complex evaluation of Socio-Economical System and Processes, together with development aspects, including complexity, and application in the Quantitative Complex evaluation of Socio-Economical Processes under dynamic and risky conditions, micro (Marzuki et al. 2012), meso (Ren et al. 2012) and macro environment are presented in this research. In terms of analysis, information is of most importance. Information dependency may be the most important key for managing information exchange to reduce project risks (Ke et al. 2012).

The Social \& Economic Systems emerged in the fifth decade of the twentieth century. At first, Social \& Economic Systems were analysed separately (Table 1). The economic development of socio-economic systems (SES) largely depends on our understanding of their nature and formation mechanisms. Quantitative evaluation of the state of such systems is also important, as it determines effective management ensuring their effective performance. Quantitative evaluation of socio-economic systems and processes may be performed using MCDM evaluation and DM methods. These methods help generating an integrated criterion reflecting various SES aspects observed in reality. Given quantitative methods of SES evaluation, such important problems associated with the economic development of a country can be solved as the determination of enterprise development strategy, the formation of flexible enterprise organizational structures, etc. (Kapliński, Peldschus 2011). Nowadays, quantitative SES evaluates and implements aspects of micro, meso and macro environments. A strategic goal for the next decade: to become the most competitive and dynamic knowledge-based economy in the world capable of sustainable economic growth (Dalal-Clayton, Sadler 2005). SEA aims to provide a process, by which the policy is developed based on a much broader set of perspectives, objectives and constraints than just those initially identified by the proponent (Brown, Thérivel 2000).

The realm of sustainability has often been depicted as the intersection of social, economic and ecological interests and initiatives. One possible solution is to take sustainability as an essentially integrative concept and to design sustainability assessment more aggressively as an integrative process. This would entail a package of regime and process design features (Gibson 2006). The second aim is to discuss the relevance of context consciousness and sensitivity in relation to one of the main aims given to SEA implementation (Hilding-Rydevik, Bjarnadóttir 2007). In theories of limited rationality, attention is seen as a scarce resource: 
decision-makers - like all other people - have a natural limited mental capacity and are therefore only able to cope within these limits and with a limited volume of information (Kornov, Thissen 2000).

SEA methodology and practice is to advance, then a common understanding of its definition and characteristics must first be achieved (Noble 2000).

Most of the work in SEA seems to be based on the assumption that the provision of rational information will help improving decision-making, but the literature points to other characteristics of real decision-making processes, including cognitive limitations, behavioural biases, ambiguity and variability of preferences and norms, distribution of decision-making between actors and in time, and the notion of decision-making as a process of learning and negotiation between multiple actors (Kornov, Thissen 2000).

The development of a formalised legal basis for SEA has been an important social innovation. While procedures for the assessment of various forms of impact existed before the evolution of legalisation of SEA, for example, in the context of land use planning, and there have been general demands on the assessment of economic effects of public policies, plans and programmes, SEA procedures are more detailed and also provide criteria, by which implementation can be judged. It is therefore important to explore its roots and its connections to other legislation (Marsden 2008).

Evaluations of the use of EIA (Morgan 2012) are positive in terms of improvements to the planning and design of projects, in the quality of decision-making and of cost-effectiveness: some deficiencies have also been identified.

Sustainable development requires the setting of environmental quality goals; institution strengthening; greater use of economic instruments; and the strengthening of procedures and assessment methods (Lee, Walsh 1992).

Strategic Environmental Assessment (SEA) is seen as an important tool for integrating the environment into decision-making (Sheate et al. 2003).

Despite similarities between SEA and EIA processes, there are some differences, largely stemming from SEA being applied at an earlier stage in the planning process than EM, which has practical significance.

If SEA is to advance in application and effectiveness, then appropriate SEA methodologies need to be established. Despite calls for SEA to develop more independently of project-level assessment, existing SEA methodologies tend to be based on project-level EIA principles. It is argued here that while SEA can perhaps utilize many of the existing methods from project-level EIA, it requires a different, more broad-brush, but structured methodological approach. Noble and Storey (2001) present state-of-the-art of SEA methodology, and a generic SEA methodological framework and an example based on the notion of the "best practicable environmental option".

If SEA is to facilitate 'strategic' changes, it needs to focus on shaping the ways, in which strategic initiatives are implemented, not just formulated. This is why follow-up, which refers to post decisional activities of SEA and strategic initiatives, is increasingly seen as crucial (Gachechiladze-Bozheskua, Fischer 2012).

It should be emphasised that the focus of this discussion is specifically on the integration of the environment into strategic decision-making, i.e. it attempts to integrate the environment 
into all policy sectors and policy-making (while recognizing that this is occurring, if at all, only in some sectors and with widely differing levels of success).

The focus is not on the wider integration associated with sustainable development, i.e. integration of environment, social and economic factors. However, sustainable development mechanisms are often driven by the need to integrate the environment into decision-making processes from which it had previously been absent, and so there is an important link between the two types of integration. 'Sustainability appraisal' and 'integrated impact assessment' (i.e. impact assessment covering social, economic and environmental aspects) are just two examples of terms used to describe strategic assessment that goes beyond Strategic Environmental Assessment (SEA) in the parameters covered (Fig. 1).

The analysis, application and creation of new instruments for the DM, formalisation of the models, criterions, analysis of hierarchical systems and processes including macro, meso and micro environments is still important.

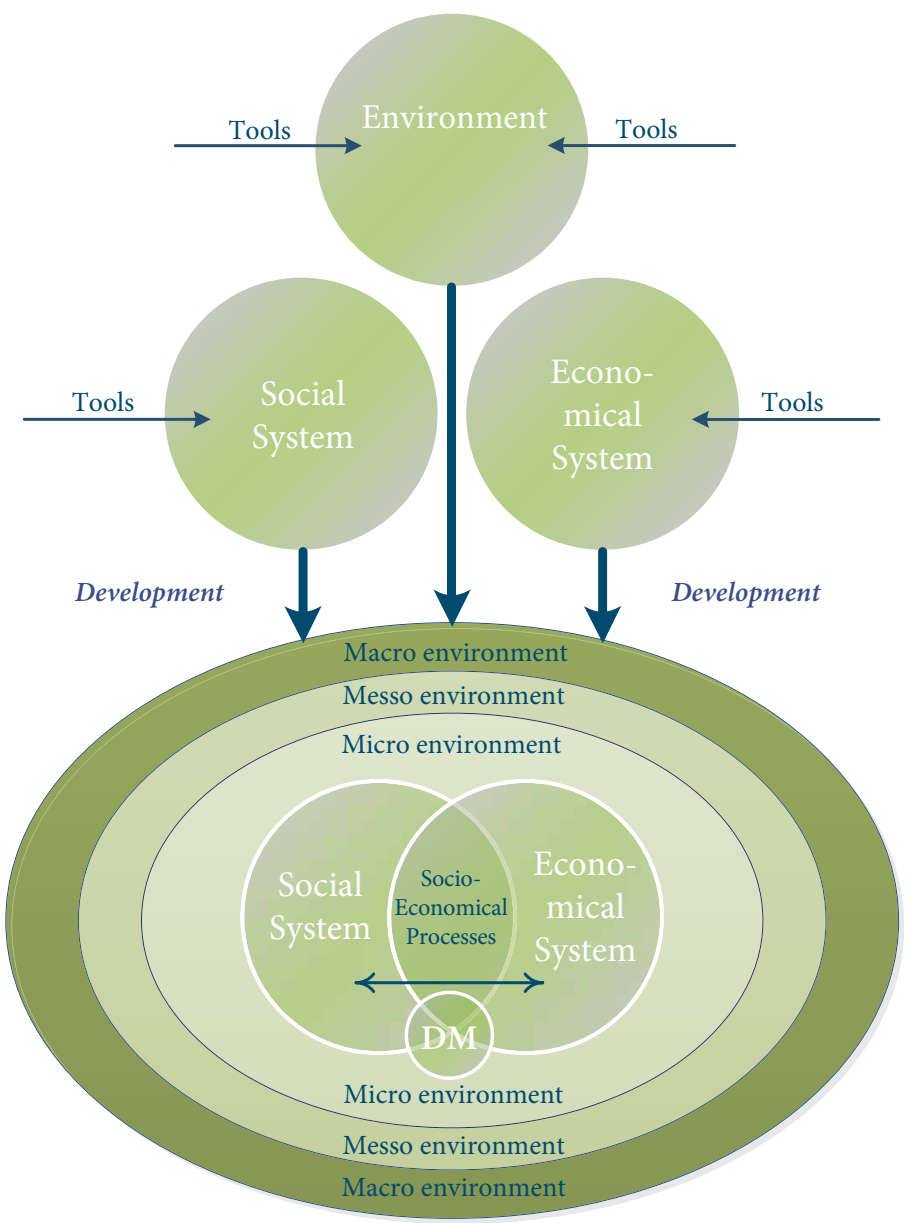

Fig. 1. SEA increasing integration of environmental, social and economic consideration 
Every SEA process should achieve certain goals, or 'principles': definition should take place in discussion between SEA and decision-making experts worldwide, representing different cultural/traditional backgrounds and level of decision-making (Verheem, Tonk 2000).

Over the years, SEA has been subjected to several interpretations, often resulting from different views on democratic processes and social considerations in decision-making. More than strictly a technical tool, as in its original form, SEA has the potential to act as a mediating instrument, bridging problem perceptions with technical solutions, steering the assessment to facilitate the integration of environmental values into decision-making processes, influencing decision-makers' capacity of acceptance (Vincente, Partidario 2006).

Research activity is evident in a number of publications. In technology and social sciences, more than 23 thousand publications were issued over the period of eighty years. The dynamics of decision-making in technology and social sciences are presented in Table 1 . The themes are topical, and in the research field, developments were presented in a large number of journals at a high recognition level, mentioned and located in ISI Web of Knowledge database.

Table 1. Dynamics of the research papers in Socio-Economic Systems Socio-Economic and Decision-Making in technology and social sciences

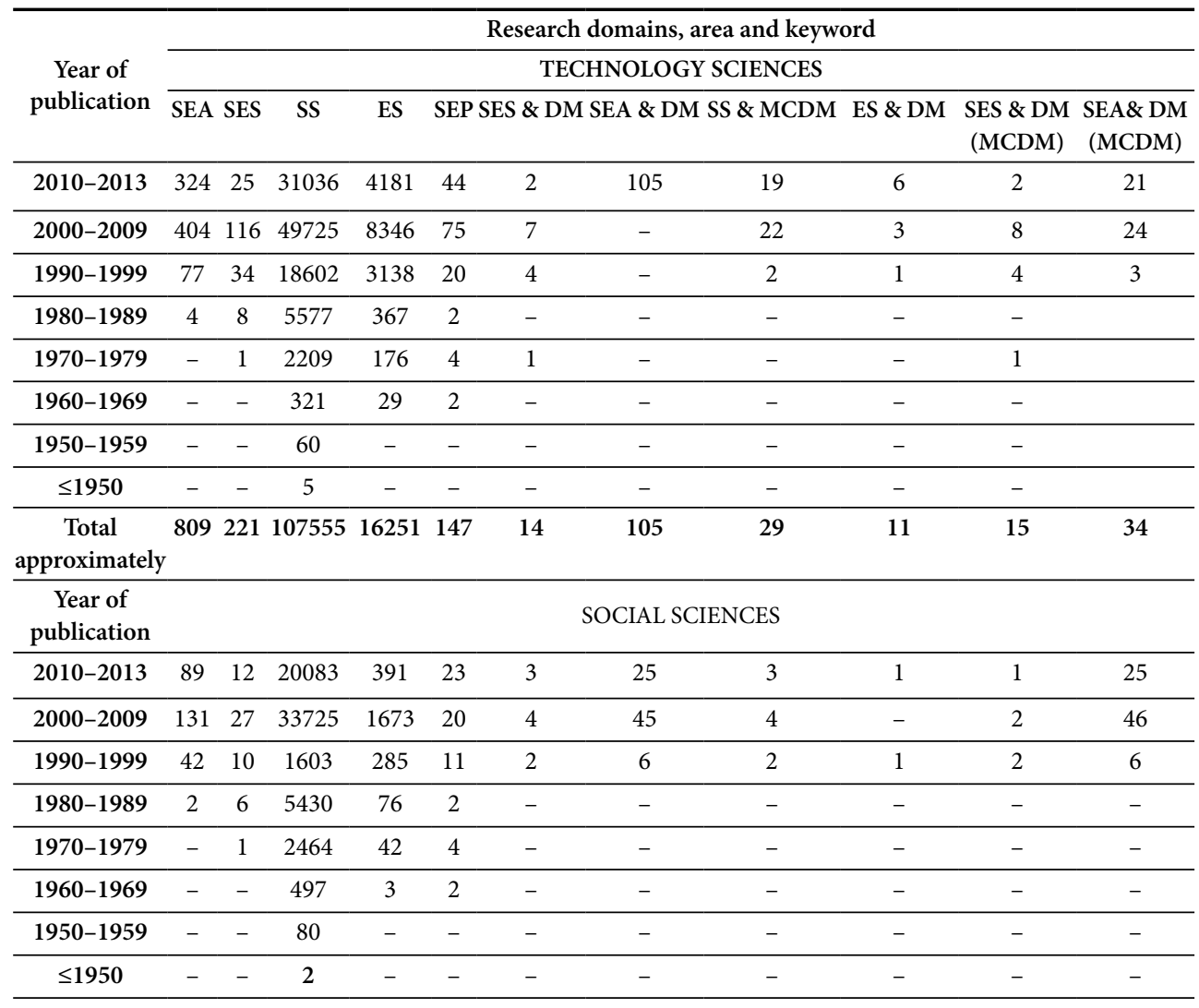

SEA - Strategic Environmental Assessment; SEP - Socio-Economic Processes; SES - Socio-Economic Systems; SS - Social Systems; ES - Economic Systems; DM - Decision-Making; MCDM - Multi Criteria Decision-Making. 
Prof Valentinas Podvezko was the first to undertake research of problems pertaining to theory of Socio-Economic systems, analysis of Quantitative Evaluation and complexity as well as decision-making instruments - MCDM methods; also, formalisation of Socio-Economic system models, analysis of quantitative evaluation models, analysis of used MCDM methods and their application in the Socio-Economic system.

\section{Research and academic career of Professor Valentinas Podvezko}

This year, Professor Valentinas Podvezko is celebrating his $70^{\text {th }}$ anniversary. He was born to an upper-level management and clerical family employed at a railway system. In 1960, he graduated from a secondary school of the city of Simferopol. In 1961, he enrolled in the Department of Mechanics and Mathematics of Lomonosov Moscow State University, specializing in Applied Mathematics. He graduated in 1966. Immediately after graduation, he started his career in the Vilnius branch of Kaunas Technical Institute, which later became Vilnius Gediminas Technical University (VGTU), as an Assistant Professor. From 1970 to 1975, he was employed as a Deputy Head of the Computing Centre of VGTU; from 1975 to 1986, he was a Senior Professor; from 1986 until

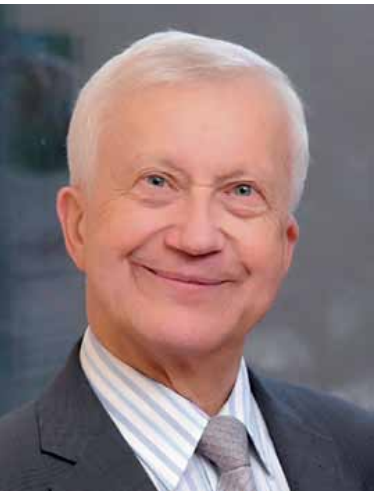

Professor Valentinas Podvezko present, he has been an Associate Professor at the Department of Mathematics (later renamed to Department of Mathematical Statistics); from 2003, he has been a Senior Research Fellow. In 1984, he was granted a PhD (Podvezko 1984) in Science at Scientific Research Institute of System Studies of the Academy of Science of the Russian Federation (Academic Supervisor: Prof Dr habil. Kazimieras Antanavičius).

In 1989, he was awarded a diploma of Associate Professor. In 1993, the diploma in mathematical sciences was ratified by the Research Council of Lithuania. On 14 September 2006, Professor V. Podvezko published his research survey entitled "Complex Evaluation of Socio-Economic Processes" (Podvezko 2006). He was granted a post-doctoral degree from the Council of Faculty of Fundamental Studies, and the Habilitation Procedure Commission. In 2006, he became a Chief Research Fellow and a Professor at the Department of Mathematical Statistics, as well as a member of the Doctoral Studies Committee at the Business and Management Faculty (04S). Professor Valentinas Podvezko is currently a member of editorial boards of following scientific journals: "Journal of Business Economics and Management” (Lithuania), “Technological and Economic Development of Economy” (Lithuania), "Economic Computation and Economic Cybernetics Studies and Research" (Romania) and "Actual Problems of Economics" (Ukraine), and a member of Lithuanian Council of Operational Research. He is an author of approx. 150 research and methodical publications, and delivered approx. 30 report papers at international and local academic conferences. He had short scientific visits to the Faculty of Economics of the Lomonosov Moscow State University, and Faculty of Mathematics at the University of Belarus, and is very active in Doctoral Studies. In 2009-2010, he participated in the Council of the Committee of Doctoral Studies 
and as a Committee member in Civil Engineering, Sociology, Economics and Mathematics more than ten times. His research focuses on Decision-Making, including MCDM method development and their modifications.

In Lithuania, MCDM methods have been developed and used for evaluating performance of socio-economic systems and solving the problems associated with analysis of MCDM methods (Ginevičius, Podvezko 2007, 2008a; Ginevičius et al. 2006, 2008a, b). In the analysis of MCDM processes, the weights of the criteria are determined and the criteria are combined into one integrated criterion (Ginevičius et al. 2008c).

Valentinas Podvezko made his contribution to the research of above-mentioned problems at all stages. He proposed new methods, such as the use of mathematical statistics in developing a set of criteria for evaluating a research object (Ginevičius, Podvezko 2005). He suggested a way of arranging a large number of evaluation criteria into a hierarchical structure (Ginevičius, Podvezko 2003a, b, 2004a, b, 2007) and suggested a way of applying well-known methods of MCDM evaluation to the analysis of a hierarchically structured systems of criteria. He also suggested a graphical-analytical MCDM method (Ginevičius, Podvezko 2008a). He analysed the defence of multi-criteria evaluation results in view of choice of preference functions and their parameters (Podvezko, Podviezko 2010) and the use of constrained and unconstrained optimisation models (Sivilevičius et al. 2011).

He performed mathematical analysis of many MCDM methods for example: the method of determining risk zones of investment in real estate (Ustinovičius et al. 2006), MCDM-1 (Ustinovičius et al. 2007), MOORA (Brauers et al. 2010), AHP (Podvezko 2009; Maskeliūnaitè et al. 2009), and comparative analysis of SAW and COPRAS methods (Podvezko 2011).

$\mathrm{He}$ analysed a number of problems in Socio-Economic Systems and processes including quantitative evaluation and complexity: economic and social development of quantitative evaluation: the organisation of manufacturing and technological processes (Ginevičius et al. 2007; Ginevičius, Podvezko 2009; Zavadskas et al. 2009a), complex evaluation of economic development (Ginevičius et al. 2006) and contracts for construction (Podvezko et al. 2010), strategic potential of an enterprise (Ginevičius et al. 2012), and enterprise marketing activities (Ginevičius et al. 2013).

\section{Recent developments: Strategic Environmental Assessment (SEA) of Social \& Economic Systems and Processes together with development of MCDM methods}

The recent developments research fields concentrate on DM, including MCDM methods (Zavadskas, Kaklauskas 2007), statistics, optimization, strategies (Zavadskas et al. 2011a; Bozejko et al. 2012), intelligent support system (Kaklauskas et al. 2011), decision support system for construction time-cost optimization (Zhang, Ng 2012), evaluation system (Ginevičius, Podvezko 2008a), etc. The instruments and supports are applied in problem solving in Social \& Economic Systems (Zavadskas, Turskis 2011; Ginevičius, Podvezko 2008b) management (Ginevičius, Podvezko 2008c; Urbanavičienè et al. 2009; Kapliński 2010), political influence dimensions of sustainability, technological change (Yang et al. 2012), and environmental impact processes (Zavadskas et al. 2011b) and other aspects (Podvezko et al. 2010). Social \& Economic system and processes including development (Tamošaitienè et al. 2010; Zavadskas 
et al. 2011a) and development including developing of alternative and processes. Broad fields as well as narrow groups consist the goal of the research in the future.

Decision-making in Social \& Economic system in risky environment is determined in different conditions (Abbasianjahromi, Rajaie 2012). In this case, evaluation of problems is possible including MCDM methods. In dynamic environment, undersell existing methods are used. For this reason, development of new MCDM methods with different types of values is an important topic. The criteria, decision-making methods and created models must be adopted in one decision support system. The existing problems solution algorithms and models must by adopted applying new conditions.

The broad fields might be divided to narrow groups by applying decision tree fields and considering research object-finding rational solutions.

In the future, the main research fields of DM\&MCDM in SEA must be developed in following aspects: green, environmental, sustainable and eco (Schiederig et al. 2012), which are presented in Fig. 2. The model must be oriented more at funding possible optimal, acceptable and feasible decisions of analysed problems. Recent development, trends together with MCDM methods, are as follow (Zavadskas et al. 2013):

- development of MCDM models, methods with different information types;

- creation of hybrid problem solving models algorithms;

- multi-stage problem solving;

- different MCDM methods combinations application;

- modelling and creation decision-making algorithms in practice;

- simulation;

- optimization;

- statistics;

- best practice.

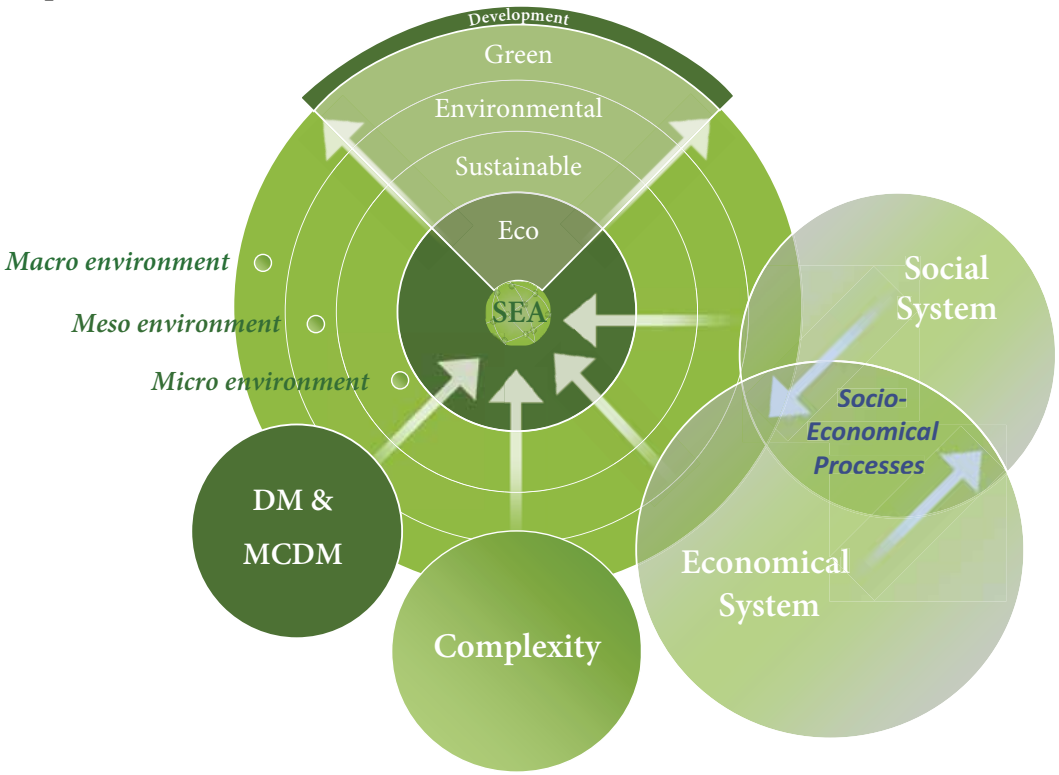

Fig. 2. Quantitative Complex evaluation of Strategic Environmental Assessment 
The magnitude and future importance of some of the problems perceived by society are directly related to the field of the Strategic Environmental Assessment, implying an inescapable burden of responsibility for a group whose technical soundness, rational approach and efficiency is highly valued and respected by the citizen (Ramirez, Seco 2012). Decision-Making must involve complexity, multi-staging, methods using different types of information. Models and decision-making algorithms must be developed and created in view of ICT products for problem solving in Strategic Environmental Assessment, etc. Systems must operate in micro, meso and macro environments and include developmental aspects.

\section{Conclusions}

This paper sets out to identify and examine what the academic literature reports on SEA as an assessment tool or process and can or should it support sustainability in Socio-Economic system development, assessment and decision-making.

According to the area of research, Prof. V. Podvezko' research work may be divided into following groups: theory of Socio-Economic systems, analysis of quantitative evaluation and complexity, and decision-making instruments - MCDM methods; formalisation of Socio-Economic system models, analysis of quantitative evaluation models, analysis of MCDM methods in use and their application for a Socio-Economic System.

\section{References}

Ahmed, K.; Sanchez-Triana, E. (Eds.). 2008. Strategic environmental assessment for policies. Washington, DC: World Bank. 222 p.

Abbasianjahromi, H.; Rajaie, H. 2012. Developing a project portfolio selection model for contractor firms considering the risk factor, Journal of Civil Engineering and Management 18(6): 879-889. http://dx.doi.org/10.3846/13923730.2012.734856

Bozejko, W.; Hejducki, Z.; Wodecki, M. 2012. Applying metaheuristic strategies in construction projects management, Journal of Civil Engineering and Management 18(5): 621-630.

http://dx.doi.org/10.3846/13923730.2012.719837

Brown, L.; Thérivel, R. 2000. Principles to guide the development of strategic environmental assessment methodology, Impact Assessment \& Project Appraisal 18(3): 183-189.

http://dx.doi.org/10.3152/147154600781767385

Brauers, W. K. M.; Ginevičius, R.; Podvezko, V. 2010. Regional development in Lithuania considering multiple objectives by the MOORA method, Technological and Economic Development of Economy 16(4): 613-640. http://dx.doi.org/10.3846/tede.2010.38

Dalal-Clayton, B.; Sadler, B. (Eds.). 2005. Strategic environmental assessment: a sourcebook and reference guide to international experience. London: Earthscan. $504 \mathrm{p}$.

Fischer, T. B. 2003. Strategic environmental assessment in post-modern times, Environmental Impact Assessment Review 23(2): 155-170. http://dx.doi.org/10.1016/S0195-9255(02)00094-X

Fischer, T. B. 2007. Theory and practice of strategic environmental assessment. London: Earthscan.

Gachechiladze-Bozheskua, M.; Fischer, T. B. 2012. Benefits of and barriers to SEA follow-up - theory and practice, Environmental Impact Assessment Review 34: 22-30.

http://dx.doi.org/10.1016/j.eiar.2011.11.006 
Geneletti, D. 2013. Ecosystem services in environmental impact assessment and strategic environmental assessment, Environmental impact assessment review, Special Issue on Ecosystem Services in EIA and SEA 40(SI): $1-2$.

Gibson, R. B. 2006. Beyond the pillars: sustainability assessment as a framework for effective integration of social, economic and ecological considerations in significant decision-making, Journal of Environmental Assessment Policy \& Management 8(3): 259-280. http://dx.doi.org/10.1142/S1464333206002517

Ginevičius, R.; Podvezko, V. 2003b. Quantitative evaluation of the significance of hierarchically structured indices, Business: Theory and Practice 3(3): 111-116.

Ginevičius, R.; Podvezko, V. 2003a. Quantitative evaluation of the significance of hierarchically structured indexes, in International Conference on Modelling and Simulation of Business System, May 13-14, 2003, Vilnius, Lithuania, 22-25.

Ginevičius, R.; Podvezko, V. 2004a. Quantitative evaluation of the strategic potential of enterprises, Business: Theory and Practice 4(1): 3-9.

Ginevičius, R.; Podvezko, V. 2004b. Hierarchical structuring of elements based on their transitivity, Business: Theory and Practice 4(3): 85-89.

Ginevičius, R.; Podvezko, V. 2005. Generation of a set of evaluation criteria, Business: Theory and Practice 6(4): 199-207.

Ginevicius, R.; Podvezko, V. 2007. Complex assessment of sustainable development of the state regions with emphasis on ecological and dwelling conditions, Ekologija 53: 41-48.

Ginevičius, R.; Butkevičius, A.; Podvezko, V. 2006. Complex evaluation of economic development of the Baltic States and Poland, Ekonomický časopis 54(9): 918-930.

Ginevičius, R.; Podvezko, V.; Andruškevičius, A. 2007. Quantitative evaluation of building technology, International Journal of Technology Management 40(1/2/3): 192-214.

Ginevičius, R.; Podvezko, V. 2008a. Multicriteria graphical-analytical evaluation of the financial state of construction enterprises, Technological and Economic Development of Economy 14(4): 452-461. http://dx.doi.org/10.3846/1392-8619.2008.14.452-461

Ginevičius, R.; Podvezko, V. 2008b. Housing in the context of economic and social development of Lithuanian regions, International Journal of Environment and Pollution (IJEP) 35(2/3/4): 309-330.

Ginevičius, R.; Podvezko, V. 2008c. Multicriteria evaluation of Lithuanian banks from the perspective of their reliability for clients, Journal of Business Economics and Management 9(4): 257-267. http://dx.doi.org/10.3846/1611-1699.2008.9.257-267

Ginevičius, R.; Podvezko, V.; Bruzge, Š. 2008a. Evaluating the effect of state aid to business by multicriteria methods, Journal of Business Economics and Management 9(3): 167-180. http://dx.doi.org/10.3846/1611-1699.2008.9.167-180

Ginevičius, R.; Podvezko, V.; Raslanas, S. 2008b. Evaluating the alternative solutions of wall insulation by multicriteria methods, Journal of Civil Engineering and Management 14(4): 217-226.

http://dx.doi.org/10.3846/1392-3730.2008.14.20

Ginevicius, R.; Gineviciene, V.; Podvezko, V. 2008c. The effectiveness of enterprise marketing system, in International Conference on Marketing and Management Sciences (ICMMS), May, 2008, Athens, Greece, 31-32.

Ginevičius, R.; Podvezko, V. 2009. Evaluating the changes in economic and social development of Lithuanian counties by multiple criteria methods, Technological and Economic Development of Economy 15(3): 418-436. http://dx.doi.org/10.3846/1392-8619.2009.15.418-436

Ginevičius, R.; Podvezko, V.; Novotny, M.; Komka, A. 2012. Comprehensive quantitative evaluation of the strategic potential of an enterprise, Economic Computation and Economic Cybernetics Studies and Research 46(1): 65-84. 
Ginevičius, R.; Podvezko, V.; Ginevičius, A. 2013. Quantitative evaluation of enterprise marketing activities, Journal of Business Economics and Management 14(1): 200-212. http://dx.doi.org/10.3846/16111699.2012.731143

Hilding-Rydevik, T.; Bjarnadóttir, H. 2007. Context awareness and sensitivity in SEA implementation, Environmental Impact Assessment Review 27(7): 666-684. http://dx.doi.org/10.1016/j.eiar.2007.05.009

Kaklauskas, A.; Kelpšienè, L.; Zavadskas, E. K.; Bardauskienė, D.; Kaklauskas, G.; Urbonas, M.; Sorakas, V. 2011. Crisis management in construction and real estate: conceptual modeling at the micro-, mesoand macro-levels, Land Use Policy 28(1): 280-293. http://dx.doi.org/10.1016/j.landusepol.2010.06.008

Kapliński, O. 2010. Review of trans-border co-operation in construction management between Lithuania, Germany and Poland, Evolution of Science and Technology 2(1): 5-18. http://dx.doi.org/10.3846/est.2010.22

Kapliński, O.; Peldschus, F. 2011. The problems of quantitative evaluation of socio-economic system development: review, Inzinerine Ekonomika - Enginering Economics 22(4): 345-355.

Ke, Y.; Wang, S. Q.; Chan, A. P. C. 2012. Risk management practice in China's public-private partnership projects, Journal of Civil Engineering and Management 18(5): 675-684. http://dx.doi.org/10.3846/13923730.2012.723380

Kornov, L.; Thissen, W. 2000. Rationality in decision and policy-making: implications for strategic environmental assessment, Impact Assessment \& Project Appraisal 18(3): 191-200. http://dx.doi.org/10.3152/147154600781767402

Lee, N.; Walsh, F. 1992. Strategic environmental assessment: an overview, Project Appraisal 7(3): 126-136. http://dx.doi.org/10.1080/02688867.1992.9726853

Marsden, S. 2008. Strategic environmental assessment in international and European law. London: Earthscan. 330 p.

Marzuki, P. F.; Permadi, H.; Sunaryo, I. 2012. Factors affecting job satisfaction of workers in Indonesian construction companies, Journal of Civil Engineering and Management 18(3): 299-309. http://dx.doi.org/10.3846/13923730.2012.698889

Maskeliūnaite, L.; Sivilevičius, H.; Podvezko, V. 2009. Research on the quality of passenger transportation by railway, Transport 24(2): 100-112. http://dx.doi.org/10.3846/1648-4142.2009.24.100-112

Morgan, R. K. 2012. Environmental impact assessment: the state of the art, Impact Assessment and Project Appraisal 30(1): 5-14. http://dx.doi.org/10.1080/14615517.2012.661557

Nilsson, M.; Dalkmann, H. 2001. Decision making and strategic environmental assessment, Journal of Environmental Assessment Policy \& Management 3(3): 305-327. http://dx.doi.org/10.1142/S1464333201000728

Nitz, T.; Brown, L. 2001. SEA must learn how policy making works, Journal of Environmental Assessment Policy \& Management 3(3): 329-342. http://dx.doi.org/10.1142/S146433320100073X

Noble, B.; Storey, K. 2001. Towards a structured approach to strategic environmental assessment, Journal of Environmental Assessment Policy \& Management 3(4): 483-508. http://dx.doi.org/10.1142/S1464333201000832

Noble, B. F. 2000. Strategic environmental assessment: what is it and what makes it strategic?, Journal of Environmental Assessment Policy \& Management 2(2): 203-224. http://dx.doi.org/10.1142/S146433320000014X

Partidario, M. R. 1996. Strategic environmental assessment: key issues emerging from recent practice, Environmental Impact Assessment Review 16(1):31-55. http://dx.doi.org/10.1016/0195-9255(95)00106-9

Partidario, M. R. 2000. Elements of an SEA framework: improving the added-value of SEA, Environmental Impact Assessment Review 20(6): 647-663. http://dx.doi.org/10.1016/S0195-9255(00)00069-X

Partidario, M. R. 2007. Scales and associated data: what is enough for SEA needs?, Environmental Impact Assessment Review 27(5): 460-478. http://dx.doi.org/10.1016/j.eiar.2007.02.004 
Partidario, M. R.; Arts, J. 2005. Exploring the concept of strategic environmental assessment follow-up, Impact Assessment \& Project Appraisal 23(3): 246-257. http://dx.doi.org/10.3152/147154605781765481

Podvezko, V. 1984. Design and analysis of complex probabilistic models of prediction: Disertation [Postroenie i analiz kompleksa modeley veroiatnostnogo prognozirovaniia] (in Russian).

Podvezko, V. 2006. Complex evaluation of social and economic processes: Habilitation. Vilnius: Technika.

Podvezko, V. 2009. Application of AHP technique, Journal of Business Economics and Management 10(2): 181-189. http://dx.doi.org/10.3846/1611-1699.2009.10.181-189

Podvezko, V. 2011. The comparative analysis of MCDA methods SAW and COPRAS, Inzinerine Ekonomika - Engineering Economics 2(22): 134-146.

Podvezko, V.; Podviezko, A. 2010. Dependence of multi-criteria evaluation result on choice of preference functions and their parameters, Technological and Economic Development of Economy 16(1): 143-158. http://dx.doi.org/10.3846/tede.2010.09

Podvezko, V.; Mitkus, S.; Trinkuniene, E. 2010. Complex evaluation of contracts for construction, Journal of Civil Engineering and Management 16(2): 287-297. http://dx.doi.org/10.3846/jcem.2010.33

Ramirez, F.; Seco, A. 2012. Civil engineering at the crossroads in the twenty-first century, Science and Engineering Ethics 18(4): 681-687. http://dx.doi.org/10.1007/s11948-011-9258-2

Ren, Y.; Skibniewski, M. J.; Jiang, S. 2012. Building information modeling integrated with electronic commerce material procurement and supplier performance management system, Journal of Civil Engineering and Management 18(5): 642-654. http://dx.doi.org/10.3846/13923730.2012.719835

Schiederig, T.; Tietze, F.; Herstatt, C. 2012. Green innovation in technology and innovation management an exploratory literature review, $R \& D$ Management 42(2): 180-192.

http://dx.doi.org/10.1111/j.1467-9310.2011.00672.x

Sheate, W. R.; Dagg, S.; Richardson, J.; Aschemann, R.; Palerm, J.; Steen, U. 2003. Integrating the environment into strategic decision-making: conceptualizing policy SEA, European Environment 13(1): 1-18. http://dx.doi.org/10.1002/eet.305

Sivilevičius, H.; Podvezko, V.; Vakriniené, S. 2011. The use of constrained and unconstrained optimization models in gradation design of hot mix asphalt mixture, Construction and Building Materials 25(1): 115-122. http://dx.doi.org/10.1016/j.conbuildmat.2010.06.050

Stoeglehner, G.; Brown, L.; Kornov, L. 2009. SEA and planning: ownership of strategic environmental assessment by the planners is the key to its effectiveness, Impact Assessment \& Project Appraisal 27(2): 111-120. http://dx.doi.org/10.3152/146155109X438742

Tamošaitienė, J.; Bartkiené, L.; Vilutienė, T. 2010. The new development trend of operational research in civil engineering and sustainable development as a result of collaboration between German-Lithuanian-Polish scientific triangle, Journal of Business Economics and Management 11(2): 316-340. http://dx.doi.org/10.3846/jbem.2010.16

Urbanavičienė, V.; Kaklauskas, A.; Zavadskas, E. K.; Seniut, M. 2009. The web-based real estate multiple criteria negotiation decision support system: a new generation of decision support systems, International Journal of Strategic Property Management 13(3): 267-286. http://dx.doi.org/10.3846/1648-715X.2009.13.267-286

Ustinovičius, L.; Podvezko, V.; Ginevičius, R. 2006. A method of determining risk zones of investment in real estate, Control and Cybernetics 35(2): 471-486.

Ustinovičius, L.; Zavadskas, E. K.; Podvezko, V. 2007. Application of a quantitative multiple criteria decision making (MCDM-1) approach to the analysis of investments in construction, Control and Cybernetics 36(1): 251-268.

Verheem, R.; Tonk, J. 2000. Strategic environmental assessment: one concept, multiple forms, Impact Assessment \& Project Appraisal 19(3): 177-182. http://dx.doi.org/10.3152/147154600781767411 
Vicente, G.; Partidário, M. R. 2006. SEA: enhancing communication for better environmental decisions, Environmental Impact Assessment Review 26(8): 696-706. http://dx.doi.org/10.1016/j.eiar.2006.06.005

Yang, L.-R.; Chen, J.-H.; Wang, H.-W. 2012. Assessing impacts of information technology on project success through knowledge management practice, Automation in Construction 22: 182-191. http://dx.doi.org/10.1016/j.autcon.2011.06.016

Zavadskas, E. K.; Ginevičius, R.; Tamošaitienè, J.; Banaitis, A. 2013. Multiple Criteria Decision Making (MCDM) methods in civil engineering: overview and trends, Bauprozessmanagement und Immobilienentwicklung: Schriftenreihe des Lehrstuhl für Bauprozessmanagement und Immobilienentwicklung. Band. 33 Munchen: Technische Universitat Munchen. (Lehrstuhl fur Bauprozessmanagement und Immobilienentwicklung, Band 33): 1-10.

Zavadskas, E. K.; Kaklauskas, A. 2007. Mehrzielselektion für Entscheidungen im Bauwesen. Stuttgart: Fraunhofer IRB Verlag.

Zavadskas, E. K.; Kaklauskas, A.; Turskis, Z.; Tamošaitienè, J. 2009. Multi-attribute decision-making model by applying grey numbers, Informatica 20(2): 305-320 [online], [cited 17 April 2013]. Vilnius: Matematikos ir informatikos institutas. ISSN 0868-4952. Available from Internet: http://www.mii.lt/ informatica/pdf/INFO750.pdf

Zavadskas, E. K.; Kaklauskas, A.; Turskis, Z.; Tamosaitiene, J.; Kalibatas, D. 2011b. Assessment of the indoor environment of dwelling houses by applying the COPRAS-G method: Lithuania case study, Environmental Engineering and Management Journal 10(5): 637-647.

Zavadskas, E. K.; Turskis, Z. 2011. Multiple criteria decision making (MCDM) methods in economics: an overview, Technological and Economic Development of Economy 17(2): 397-427. http://dx.doi.org/10.3846/20294913.2011.593291

Zavadskas, E. K.; Turskis, Z.; Tamosaitiene, J. 2011a. Selection of construction enterprises management strategy based on the SWOT and multi-criteria analysis, Archives of Civil and Mechanical Engineering 11(4): 1063-1082. http://dx.doi.org/10.1016/S1644-9665(12)60096-X

Zhang, Y.; Ng, S. T. 2012. An ant colony system based decision support system for construction time-cost optimization, Journal of Civil Engineering and Management 18(4): 580-589.

http://dx.doi.org/10.3846/13923730.2012.704164

Jolanta TAMOŠAITIENĖ. Assoc. Prof, Dr, Vice-Dean of Civil Engineering Faculty, working in the Department of Construction Technology and Management at Vilnius Gediminas Technical University, Lithuania. Since 2013, she has been a member of the Editorial Board of "The Journal of Engineering, Project, and Production Management". Since 2011, she is a member of the Editorial Board of the journal "Technological and Economic Development of Economy". Since 2009, she has been a member of EURO Working Group OR in Sustainable Development and Civil Engineering, EWG-ORSDCE. Since 2013, she has been a board member of Engineering, Project, and Production Management Association. She published 50 research papers. Research interests: miscellaneous management areas (enterprise, construction project, etc.), risk assessment, construction project administration, building life-cycle, construction technology and organisation, decision-making and grey system theory, Decision-Making (DM), statistics, optimization, strategies, game theory, intelligent support system, Sustainable Development: developing of alternative construction processes, economic and other aspects, sustainable development challenges for business and management in construction enterprises, environmental impact processes, and others.

Oleg KAPLIŃSKI. Professor of Civil Engineering at Poznań University of Technology, Poland. Honorary Doctor of VGTU. He is a member of Civil Engineering Committee of Polish Academy of Science and Vice-Chairman of the Section of the Engineering of Construction Projects in this Committee. He is a board member of EURO Working Group OR in Sustainable Development and Civil Engineering. His research interests include the organisation and modelling of construction processes, theory of decision-making. 